\title{
LIFE INSURANCE RECEIPTS: THE MYSTERY OF THE NON-BINDING BINDER
}

WHILE life insurance contracts are not ordinarily effective until delivery of the policy. ${ }^{1}$ it is common for insurance companies to issue so-called binding receipts.2 The applicant obtains a receipt by paying his first premium at the time of application. In return, the binder purports to extend covernge before the policy is delivered. ${ }^{3}$ Since an application is merely an offer. ${ }^{4}$ revocable at any time, insurance companies introduced the binder to protect themselves from an applicant's possible change of mind." Such revocations result in outof-pocket losses to the company due to expenditures for medical examinatiun and investigation of the applicant. ${ }^{6}$ These losses, though individually small, may be cumulatively quite substantial. Moreover, where the face amount of the policy is small, ${ }^{i}$ such losses represent a proportionately large overineal cost. ${ }^{\mathrm{s}}$ By securing payment in advance the company effectively aroils such losses since the premium is generally sufficient to cuver the company's custs. Even if a revoking applicant is entitled to return of his payment the amount involved is too small to make legal action worthwhile. ${ }^{9}$

1. VANCE, Ixsuraxce $\$ \$ 35,42$ (3d ed. 1951). For a discussion of when delivery accurs, see Patterson, The Deliz'ry of a Life-Insurance Policy, 33 Hanv. L. Rew. 193 (1919).

2. For general discussions of the problems raised by binding receipts, see Havighurst, Life Insurance Binding Receipts, 33 ILL. L. REv. 1SO (1938); Wilkinson, Bitding Receipts-Three Decades Later, 42 Proceedras of Ax. Life Conventios, Leonal Sectro: is (1949); Comment, Operation of Binding Receipts in Life Insurance, 44 YALE L.J. 1223 (1935).

3. Id. at 12245. For a collection of different binding receipt clauses used by various companies, see Note, 2 A.L.R.2d 943, 960-2 nn.7-9 (1948).

4. VaACE, INSURAXCE 209 (3d ed. 1951).

5. Havighurst, supra note 2 , at $180-1$; Wilkinson, supra note 2 , at 18 ; Comment, 44 YALE L.J. 1223, 1224 (1935).

6. Even if the company can legally recover its loss, which it probably cannot, 1 Covch, Cyclopeda of Issuraxce LAw $\$ 93$ (1929), the amount involved is too small to justify litigation.

7. Binding receipts are often used in connection with small policies, Comment, 44 Y.ALE L.J. 1223, $1225 \mathrm{n.10}$ (1935), a fact which is reflected in the number of policies with face amounts of under $\$ 1,000$ appearing in litigated cases. See, c.g., Western \& Southern Life Ins. Co. v. Vale, 213 Ind. 601, 12 N.E.2d 350 (1938) (\$̧761 policy); Reck v. Prudential Ins. Co. of America, 116 N.J.L. 444, 184 Atl. 777 (1936) (\$1000 policy); Cheel v. Pilot Life Ins. Co., 215 N.C. 36, 1 S.E.2d 115 (1939) (\$125 policy); Colorado Life Co. v. Teague, 117 S.W.2d 849 (Tex. Civ. App. 1938) (\$500 policy). In 1949 there were 109 million industrial insurance policies in force with an average face value of $\$ 300$ as compared with 65 million larger life insurance policies. Comment, Cost and Coricroge of Indastrial Life Insurance, 61 YALE L.J. 46, 47 (1952).

8. For a general discussion of the effects of high overhead costs on industrial insurance policies, see $i d$. at $49-54$.

9. See note 7 supra. The amount paid in advance is generally under \$100. Comment, 44 YALE L.J. 1223, 1225 n.10 (1935). Aforeover, in some binders the applicant specifically 
Moreover, the binder reduces the likelihood of revocation by the applicant. $\mathrm{He}$ may believe that he is protected from the moment he pays his first premium, regarclless of the exact terms of the binder. This sometimes unwarranted ${ }^{10}$ belief is often encouraged by agents' sales talks indicating that coverage has already commenced. ${ }^{11}$ While, as a general rule, the bincler creates liability at some point prior to delivery, ${ }^{12}$ its effect may not be as sweeping as the applicant is led to believe. ${ }^{13}$

The use of life insurance binding receipts has not been subject to regulation. While voluminous insurance regulations can be found in the statutes of every state, ${ }^{14}$ there are no clauses pertaining to binding receipts. ${ }^{16}$ Whatever

agrees to forfeit the amount paid if he revokes his offer. See, c.g., Albers v. Sccurity Mutual Life Ins. Co., 41 S.D. 270, 170 N.W. 159 (1918).

10. See pages 525-6 infra.

11. Havighurst, supra note 2, at 181. Cheek v. Pilot Life Ins. Co., 215 N.C. 36, 39, 1 S.E.2d 115, 116-17 (1939), contains a frank statement of an agent to this effect: "I tell the people this is something in force right now. . . . I tell them that most of the time. . . That is one of the biggest sales talks, that I am selling something that will give them protection right now. That is what I emphasized to Mr. Cheek."

12. Even where recovery is denied, it is generally conceded that if the applicant is in good health at the time the company approves his policy, the binder protects him from that time until delivery of the policy. Cooksey v. Mutual Life Ins. Co., 73 Ark. 117, 83 S.W. 317 (1904); Braman v. Mutual Life Ins. Co., 73 F.2d 391 (8th Cir. 1934).

13. See, c.g., Cheek v. Pilot Life Ins. Co., 215 N.C. 36, 1. S.E.2d 115 (1939) (recovery denied despite agent's statement). But cf. Mayfield v. Montana Life Ins. Co., 62 Mont. 535, 205 Pac. 669 (1922).

14. Ala. Code tit. 28 (1940) ; 6 Ark. Stat. AnN. tit. 66 (1947) ; Ariz. Cone c. 61 (1939); Cal. Insurance Code (Deering, 1950); 3A Colo. Stat. Ann. c. 87 (1935); Conn. Gen. Stat. tit. 42 (1949); 10 Del. Code Ann. tit. 18 (1953); Fla. Stat. AnN. tit. 35 (1941); Ga. Code Ans. tit. 56 (1935); 7 Idaho Code tit. 41 (1947); Ill. Stat. ANn. c. 73 (Smith-Hurd, 1940) ; 8 Ind. Stat. ANN. tit. 39 (Burns, 1952); Iown Codk Ans. tit. 20 (1946); Kan. Gen. Stat. c. 40 (1949); KY. Rev. Stat. cc. 297-304 (1953); 15 La. Rev. Stat. tit. 22 (1950) ; 2 Me. Rev. Stat. c. 56 (1944); 2 Mo. Cove AnN. art. 48A (Flack, 1951); Mass. Laws Ann. c. 175 (1948); 17 Mich. Stat. Ann. tit. 24 (1943) ; Mrnn. Stat. Ann. cc. $60-8$ (1945); Miss. Code Ann. tit. 22, c. 3 (1942); 19 Mo. Stat. Anv. tit. 26, c. 376 (Vernon, 1952); 3 Mont. Rev. Code tit. 40 (1937); 3A Neb. Rev. Stat. c. 44 (1952) ; 4 Nev. Comp. Laws $\$ 3540$ et seq. (1929) ; 2 N.H. Rev. Laws cc. 323-31 (1942); N.J. Stat. Ann. tit. 17 (1937); 5 N.M. Stat. AnN. c. 60 (1941) ; N.Y. Insurance Law (1949) ; 28 N.C. Gen. Stat. c. 58 (1949) ; N.D. Rev. Code tit. 26 (1943) ; 6 Ohro Gen. Code Ans. $\$ 9339$ et seq. (Page, 1938); Orla. Stat. Ann. tit. 36 (1951) ; 7 Ore Comp. Laws Ann. tit. 101 (1940) ; Pa. Stat. AnN. tit. 40 (Purdon, 1930) ; R.I. GEN. Laws c. 150 (1938); 4 S.C. Code tit. 37 (1952) ; 1 S.D. Cone tit. 31. (1939); Tenn. Code ANN. tit. 14, c. 6 (Williams, 1934); Tex. Insurance Cont (1951) ; 4 Utah Code AnN. tit. 31 (1953) ; VT. Stat. tit. 42, pt. III (1947) ; 6 VA. Code tit. 38 (1950) ; 8 Wash. Rev. Stat. Ann. tit. 45 (Remington, 1931) ; W. VA. Code c. 33 (1949); Wis. Stat. cc. 200-10 (1951) ; 3 Wyo. Comp. Stat. c. 52 (1945).

15. See note 14 supra. Nor was insurance included among the regulated public callings at common law. 3 Holdsworth, A History of English Law 446-8 (4th ed. 1935). The early English insurance law was, in fact, designed to protect the insurer because he was to some extent at the mercy of the insured. Patterson, The Insurance CommisSIONER IN THE UNITEd STates 245 (1927). 
legal restraints ${ }^{16}$ exist are the result of a relatively recent body of case law. But nearly a century of litigation between beneficiary and insurer has leveloped more confusion than regulation.

\section{Conflicting Results and Theories}

Insurance Co. '. Young's Adm'r ${ }^{17}$ has profoundly influenced binding receipt litigation. There the company had issued a binder, rejected the application, and sent a different policy to the applicant, prior to his fatal injury. The applicant did not accept the policy offered prior to death. The Supreme Court found an offer by the applicant, rejection, an unaccepted counter offer and nu contract. ${ }^{18}$ The binding receipt, terminated by rejection of the original application, created no liability. The result in Yommg's Adm'r, valid on its own facts, was followed especially in other early cases without regard to its applicability to other fact situations. Later decisions ignored the iact that the Supreme Court did not consider the effect of a binding receipt where death intervened prior to the company's rejection. ${ }^{19}$ Thus, it becane authority for the proposition that an insurance company has an absolute right to reject liability after the applicant's death. ${ }^{20}$

This doctrine met its first serious challenge in Starr $\%$. Mutual Life Ins. Co. of N.Y. ${ }^{21}$ In that case the company actually accepted the application a few hours after the applicant's death. The beneficiary sued on a receipt stating that insurance was to be in effect "from date" if accepted by the Company" in its home office. Recovery was allowed on the ground that the clause was ambiguous and must be construed against the company.?2

Ever since the Starr case broke with precedent, the legal effect of hinders has been increasingly in doubt. Recorery is apparently rejected on one ground or another in Arkansas, ${ }^{23}$ Illinois, ${ }^{24}$ Iowa, ${ }^{25}$ Kentucky,, ${ }^{20}$ Louisiana, ${ }^{27}$

16. Public relations considerations may exert some regulatory pressure. Cumment, Cost and Coa'crage of Industrial Life Insurance, 61 YaLe L.J. 46, $58-9$ (1952).

17. 23 Wall. 85 (U.S. 1S74).

18. Id. at 105. For a very different approach to offer and acceptance in insurance law, see Broidy v. State Miutual Life Assur. Co., 1S6 F.2d 490 (2d Cir. 1951).

19. See, e.g., Steinle v. New York Life Ins. Co., \$1 Fed. 489 (5th Cir. 1897); Mohrstadt v. Mutual Life Ins. Co., 115 Fed. 81 (Sth Cir. 1902); Cooksey v. Mfutual Life Ins. Co., 73 Ark. 117, 83 S.W. 317 (19u4).

20. Mohrstadt v. Mutual Life Ins. Co., supra note 19. For a collection of eases applying this rigid doctrine, see Havighurst, stipra note 2 , at 182. This application of Youmg's Administrator has been severely criticized. Wilkinson, supra note 2, at 22-3.

21. 41 Wash. 228, 83 Pac. 116 (1905).

22. Ia. at 231-2, 83 Pac. at 117 .

23. Cooksey r. Mutual Life Ins. Co., 73 Ark. 117, 83 S.W. 317 (1904).

24. Gerrib v. Northwestern Mutual Life Ins. Co., 256 Ill. App. 505 (1930).

25. See Reynolds v. Northwestern Mutual Life Ins. Co., 189 Iowa 76, 80-1, 176 N.W. 207, 209 (1920) (dicta states that on different facts recovery would be allowed).

26. Northwestern Mutual Life Ins. Co. v. Neafus, 145 Ky. 563, 140 S.W. 1026 (1911). Accord, Indiana Nat. Life Ins. Co. v. Maines, $191 \mathrm{Ky} .309,230$ S.W. 54 (1921). Contra: Halle v. Lew York Life Ins. Cu., 22 Ky. L.R. 740, 58 S.W. 822 (1900).

27. Gonsoulin v. Equitable Life, 152 La. S65, 94 So. 424 (1922). 
Minnesota, ${ }^{28}$ North Carolina, ${ }^{29}$ Oregon, ${ }^{30}$ West Virginia ${ }^{81}$ and Wyoming. ${ }^{32}$ It appears to be allowed on a variety of theories in Alabama, ${ }^{33}$ Georgia, ${ }^{34}$ Indiana, ${ }^{35}$ Massachusetts, ${ }^{36}$ Missouri, ${ }^{37}$ Montana, ${ }^{38}$ New Jersey, ${ }^{38}$ Ohio, ${ }^{40}$ Pennsylvania, ${ }^{41}$ South Dakota ${ }^{42}$ and Washington. ${ }^{43}$ And federal courts of appeals are split, with earlier cases denying recovery, ${ }^{44}$ and later ones allowing it. ${ }^{45}$

The split in authority is made more dramatic by contradictory decisions within Michigan, ${ }^{46}$ New York, ${ }^{47}$ South Carolina ${ }^{48}$ and Texas. ${ }^{40}$ New York

28. Olson v. American Central Life Ins. Co., 172 M[inn. 511, 216 N.W. 225 (1927).

29. Cheek v. Pilot Life Ins. Co., 215 N.C. 36, 1 S.E.2d 115 (1939).

30. See Francis v. Mutual Life Ins. Co. of New York, 55 Ore. 280, 291-2, 106 Pac. 323, 327 (1910) (dictum).

31. Kronjaeger v. Travelers Ins. Co., 124 W. Va. 730, 22 S.E.2d 689 (1942).

32. Raymond v. Nat. Life Ins. Co., 40 Wyo. 1, 273 Pac. 667 (1929).

33. National Life \& Accident Co. v. Clayton, 254 Ala. 413, 48 So.2d 180 (1950).

34. National Life \& Accident Co. v. Moore, 83 Ga. App. 289, 63 S.E.2d 447 (1951); Interstate Life \& Accident Co. v. Stonecypher, 54 Ga. App. 497, 188 S.E. 294 (1936). But cf. Maddox v. Life \& Casualty Co. of Tenn., 79 Ga. App. 164, 53 S.E.2d 235 (1949).

35. Western \& Southern Life Ins. Co. v. Vale, 213 Ind. 601,12 N.E.2d 350 (1938); Western \& Southern Life Ins. Co. v. Lottes, 116 Ind. App. 559, 64 N.E.2d 405 (1946).

36. See De Cesare v. Metropolitan Life Ins. Co., 278 Mass. 401, 407, 108 N.E. 154, 156 (1932) (dictum that coverage commences only with acceptance of policy by the insurer).

37. Wolfskill v. American Union Life Ins. Co., 237 Mo. App. 1142, 172 S.W.2d 471 (1943) ; Reed v. Prudential Ins. Co., 229 Mo. App. 90, 73 S.W.2d 1027 (1934).

38. Mayfield v. Montana Life Ins. Co., 62 Mont. 535, 205 Pac. 669 (1922) scmlle.

39. Reck v. Prudential Ins. Co. of America, 116 N.J.L. 444, 184 At1. 777 (1936).

40. Duncan v. John Hancock Mutual Life Ins. Co., 137 Ohio St. 441, 31 N.E.2d 88 (1940) ; Prudential Ins. Co. v. Howard, 18 Ohio Law Abstract 688 (1935). But cf. Leube v. Prudential Life Ins. Co. of America, 147 Ohio St. 450, 72 N.E.2d 76, 60 Hakv. L. Rev. 1164 (1947).

41. Stonsz v. Equitable Life Assur. Soc., 324 Pa. 97, 187 Atl. 403 (1936).

42. Albers v. Security Mutual Life Ins. Co., 41 S.D. 270, 170 N.W. 159 (1918).

43. Starr v. Mutual Life Ins. Co. of N.Y., 41 Wash. 228, 83 Pac. 116 (1905).

44. Steinle v. New York Life Ins. Co., 81 Fed. 489 (5th Cir. 1897); Mohrstadt v. Mutual Life Ins. Co., 115 Fed. 81 (8th Cir. 1902) ; Braman v. Mutual Life Ins. Co., 73 F.2d 391 (8th Cir. 1934).

45. National Life \& Accident Co. v. Holbrook, 100 F.2d 780 (5th Cir. 1939); Gaunt v. John Hancock Mutual Life Ins. Co., 160 F.2d 599 (2d Cir.), cert. denicd, 331 U.S. 849 (1.947). In neither of these cases was the court's decision affected by Erie R.R. v. Tompkins, 304 U.S. 64 (1938), since there was no conclusive state ruling on the question.

46. Recovery allowed: N.Y. Life Ins. Co. v. Abromietes, 254 Mich. 622, 236 N.W. 769 (1931). Recovery denied: Smiley v. Prudential Ins. Co. of America, 321 Mich. 60, 32 N.W.2d 48 (1948).

47. Recovery allowed: Hart v. Travellers Ins. Co., 236 App. Div. 309, 258 N.Y. Supp. 711 (2d Dep't), aff'd without opinion, 261 N.Y. 563, 185 N.E. 739 (1932). Recovery denied: Corning v. Prudential Ins. Co. of America, 248 App. Div. 187, 288 N.Y. Supp. 661 (2d Dep't), aff'd without opinion, 273 N.Y. 668, 8 N.E.2d 338 (1936). For other New York cases see notes 51, 53, 54 infra.

48. Recovery allowed: Stanton v. Equitable Life Assur. Soc., 137 S.C. 396, 135 S.E. 367 (1926). Recovery denied: Hyder v. Metropolitan Life Ins. Co., 183 S.C. 98, 190 S.E. 
with most cases has also achieved most confusion. The leading case of Hart v. Travellers Ins. Co. ${ }^{50}$ allowed recovery, and the next case followed suit. ${ }^{31}$ But Corning v. Prudential Ins. Co. of Amcrica.:2 and three succeeding cases denied recovery. ${ }^{33}$ The most recent $\mathrm{New}$ York decision distinguished Corning and its progeny, allowing recovery on the authority of the Hart case. ${ }^{54}$ The confusion in the other doubtful jurisdictions is only slightly less pronounced. ${ }^{85}$

\section{Terms of the binder:}

\section{Verbal and Factual Contexts}

The result in a given case may depend in part on the binling receipt in question. Although most receipts are similar in their overall provisiuns, their exact terms may vary in as many ways as there are insurance companies.5 These differences have been seized upon by several cuurts to explain conflicting results in otherwise identical fact situations, ${ }^{5 \pi}$ and one court has suggested that because of these differences no case can be a binding precedent for any other. ${ }^{58}$

Although binding receipts vary in their wording, commentators have classi-

239 (1937). See also Moore v. Palmetto State Life Ins. Co.,-S.C. -, 73 S.E.2d 688 (1952) (recovery allowed primarily on estoppel, but language in confict with $H_{y}$ der case).

49. Recorery allowed: Colorado Life Co. v. Teague, 117 S.W.2d 849 (Tex Civ. App. 1938). Recovery denied: Beaty v. Southland Life Ins. Co., 28 S.W.2d 895 (Tex. Civ. App. 1930).

50. 236 App. Div. 369, 258 X.Y. Supp. 711 (2d Dep't), aff'd, 261 N.Y. 563, 185 N.E. 739 (1932).

51. Buono v. Prudential Ins. Co. of America, 240 App. Div. 898, 267 X.Y. Supp. 972 (2d Dep't 1933).

52. 248 App. Div. 187, 288 N.Y. Supp. 661 (2d Dep't), aff'd, 273 N.Y. 668, 8 N.E.2d 338 (1936).

53. Arcuri v. Prudential Ins. Co. of America, 24S Apn. Div. 501, 290 N.Y. Supp. 567 (1st Dep't 1936) ; Hughes r. John Hancock IIutual Life Ins. Co., 254 .1pp. Div. 570, 3 N.Y.S.2d 899 (2d Dep't 1938); Martin v. Equitable Life Assur. Soc. of U.S., 58 N.Y.S.2d 848 (S. Ct. 1945).

54. Speronza v. Phoenix Mutual Life Ins. Co. of Hartford, 272 App. Div. 770, 69 N.Y.S.2d 397 (2d Dep't 1947).

55. In none of these jurisdictions do the later cases satisfactorily distinguish the earlier contradictory precedents, nor du they disapprove them. See cases cited notes $51-4$ supra.

56. In fact the same cumpany may use several binding ruceipt forms, each having a different wording. Compare form used by the John Hancock Company in Dunean v. John Hancock Mutual Life Ins. Co., 137 Ohio St. 441. 443-4, 31 N.E.3d \&8, 90-1 (1940), critl: the form used by the same company in Gaunt v. John Hancock Mfutual Life Ins. Co, 160 F.2d 599, 600 n.1 (2d Cir. 1947). For a collection of varying binding receigts in current use see Note, 2 A.L.R.2d 960-2 nn.7, \&, 9 (1948).

57. See, e.g., Gaunt v. John Hancock Mutual Life Ins. Lo., 160 F.2d 599, 602 (2d Cir. 1947); Hyder v. Metropolitan Life Ins. Co., 183 S.C. 98, 119, 190 S.E. 239, 248 (1937).

58. Stonsz v. Equitable Life Assur. Soc, $324 \mathrm{~Pa} .97,100,187$ Atl. 403,405 (1936). 
fied them within two main categories: $:^{50}$ the insurable risk type, ${ }^{60}$ and the approval type. The former ordinarily provides that if the applicant is insurable under the company's rules coverage commences when the first premium is paid and the bincler issued. ${ }^{61}$ Approval binders typically state that coverage commences from payment provided the company accepts the application at its home office. ${ }^{62}$ Either form effectively protects the company from a change of mind on the part of the applicant. ${ }^{03}$ But writers have suggested that only the insurable risk type protects the applicant in the interval between completion of the application and issuance of the policy. ${ }^{04}$ In the light of more recent cases this assumption requires reexamination.

\section{Fact situations in the cases:}

Another theory advanced as explaining the apparent inconsistency of the cases, is that they arise in several distinct factual contexts. ${ }^{.6}$ Basically, three distinct factual situations exist. The first arises where the company approves the policy in ignorance of the applicant's death or other marked change of condition, and later refuses payment. In the second the company makes a counter offer or rejects the risk in ignorance of death or other marked change in the applicant's condition. ${ }^{68}$ The third, and most frequently litigated situation, ${ }^{67}$ arises where death or other change occurs prior to any action by the company, which then rejects the applicant on the basis of the post binder event.

59. Comment, 44 YALE L.J. 1223 (1935). While there are several variations of the approval binder, they may be treated as one type. Wilkinson, supra note 2, at 20 . There is a third type of receipt by which the company grants an unconditional temporary contract of insurance for the interval between filing of the application and action on it by the insurer. VANCE, INSURANCE 241 (1951). But this form is rare; and raises few legal problems. Ibid.; see also Goble, Cases on Insurance 44 (1949).

60. These are also called "satisfaction binders," Patterson, Cases on Insurance: 629 (1947).

61. Typically the crucial part of this type of receipt states: "Insurance subject to the terms and conditions of the policy contract, shall take effect as of the date of this receipt, provided the applicant is on this day ... an insurable risk, and the application is otherwise acceptable on the plan and for the amount and at the rate of premium applied for. ..." Stonsz v. Equitable Life Assur. Soc., 324 Pa. 97, 100, 187 Atl. 403, 404 (1936).

62. Typically, approval binders contain the following provision: "[W]hen stch deposit is equal to the full first premium on the policy applied for and such application is approved at the Home Office of the Company for the Class, Plan and Amount of insurance applied for, then ... the amount of insurance will be in force from the date of this receipt. . . National Life \& Accident Ins. Co. v. Moore, 83 Ga. App. 289, 63 S.E.2d 447, 448 (1951).

63. Comment, 44 Y ALE L.J. 1223, 1225 (1935).

64. Id. at 1226; VANCE, Cases ON INSURANCE 143-5 (3d ed. 1940).

65. Vance, Cases on Insurance 145-7 n.26 (3d ed. 1940).

66. VANCE, op. cit. supra note 65, at 145-6, divides this class into two: one for counteroffers and one for rejections. Since a counter-offer constitutes a rejection of the original offer, Insurance Co. v. Young's Adm'r, 23 Wall. 85 (U.S. 1874), it is difficult to see how this distinction can justify differing results.

67. See pages 530-1 infra. 
If the decisions within the various types of factual situations are relatively consistent, the apparent confusion is resolved into a matter of factual analysis. And if whatever conflict appears within a fact category can be explained by a distinction between insurable risk and approval type binders, the situation would be clarified. The cases will be examined to determine whether a combination of both explanations removes the apparent conflict.

\section{Company Accepts After Death}

An insurable risk type binder probably protects the beneficiary where death is followed by acceptance of the application. The company by its post-mortem acceptance has confirmed the applicant as an insurable risk, thus satistying the sole condition of the binder. ${ }^{68}$ It is, therefore, difficult to see hw: it cuuld deny liability. The total absence of litigation in this situatiun probably indicates that even the less liberal companies are not inclined to challenge the heneficiary's claim.

However, where "approval" binders are employed the result is less clear. Some courts treat the binder as an offer hy the applicant to the company. They reason that the offer was automatically revoked because its suljest matter (the applicant's life) ceased to exist before the application was accepted by the company. ${ }^{69}$ However, recent cases have generally allowed recovery. These later cases apply two doctrinal approaches. First, the binder effects coverage at the time of payment as otherwise the company is receiving payment for a period in which it assumes nu risk. ${ }^{11}$ Second, the intent of the parties was to effect coverage upon acceptance, retroactive to the date of the binder. ${ }^{2}$

\section{Good Faith Counter-Offer or Rejection}

Where an insurable risk type binder is in effect, the company's subsequent rejection or counter-offer has no legal effect if not communicated to the applicant. The sole question is whether the applicant was insurable un the date of the receipt. ${ }^{73}$ If he was not, then his beneficiary cannot recover ${ }^{74}$

68. See binding receipt quoted note 61 sußra.

69. Paine v. Pacific Miutual Life Ins. Co., 51 Fed. 689, 692 (8th Cir. 1892); Braman v. MIutual Life Ins. Co., 73 F.2d 391, 397 (Sth Cir. 1934).

70. National Life \& Accident Ins. Co. v. Moore, \&3 Ga. App. 28, 63 S.E.2d 447 (1951); Interstate Life \& Accident Co. v. Stonecypher, 54 Ga. App. 497, 188 S.E. 294 (1936); De Cesare v. Metropolitain Life Ins. Co, 278 Mass. 401, 180 X.E 154 (1932); New York Life Insurance Co. v. Abromietes, 254 MIich. 622, 236 N.W. 769 (1931) ; Albers v. Security Mutual Life Ins. C., 41 S.D. 270,170 N.W. 159 (1918).

71. Starr v. Miutual Life Ins. Co. of N.Y., 41 Wash. 228, 83 Pac. 116 (1905)* Albers v. Security Mutual Life Ins. Co., supra. note 70.

72. National Life \& Accident Ins. Co. v. Mloure, 83 Ga. App. 289, 292, 03 S.E.2d 447,448 (1951).

73. Reynolds v. Northwestern Mutual Life Ins. Co., 189 Iowa 76, 176 N.W. 207 (1920).

74. Ibid.; Gonsoulin v. Equitable Life, 152 La. 865, 94 So. 424 (1922). 
but if he was, the company cannot avoid liability. ${ }^{75}$ The protection that the binder gives the insurable applicant is not terminated until he receives notice of rejection. ${ }^{76}$

Where an approval binder is issued, communication to the applicant of rejection or counter-offer does not determine the result. Thus, a beneficiary may recover although the applicant knew of a counter-offer. ${ }^{77}$ But the majority view allows the company to terminate liability by an uncommunicated decision to reject the applicant. ${ }^{78}$ This position permits the company to prevent recovery by, in effect, talking to itself. ${ }^{70} \mathrm{~A}$ possible explanation for this surprising doctrine may be that in cases where it was invoked the applicant was not an insurable risk. ${ }^{80}$

\section{Rejection Because of Interim Death}

Where an applicant holds an insurable risk binder and the company rejects the policy due to intervening death, recovery is generally allowed, absent proof of non-insurability. ${ }^{81}$ But there is a dissenting view, expressed in

75. Western \& Southern Life Ins. Co. v. Vale, 213 Ind. 601, 12 N.E.2d 350 (1938) (applicant rejected because company doubted he would pay premiums); Stonsz v. Equitable Life Assur. Soc., 324 Pa. 97, 187 Atl. 403 (1936) (counter-offer); Stanton v. Equitable Life Assur. Soc., 137 S.C. 396, 135 S.E. 367 (1926) (rejection based on previous alcoholism though presently insurable).

76. Ibid.; Stonsz v. Equitable Life Assur. Soc., 324 Pa. 97, 187 Atl. 403 (1936).

77. Halle v. N.Y. Life Ins. Co., 22 Ky. L.R. 740, 58 S.W. 822 (1900) (counter-offer subject of extended negotiations between applicant and company).

78. Leube v. Prudential Ins. Co. of America, 147 Ohio St. 450, 72 N.E.2d 76 (1947) (temporary coverage created by binder and terminated by decision to reject); Mohrstadt v. Mutual Life Ins. Co., 115 Fed. 81 (8th Cir. 1902) ; Raymond v. National Life Ins. Co., 40 Wyo. 1, 273 Pac. 667 (1929); Corning v. Prudential Ins. Co. of America, 248 App. Div. 187, 288 N.Y. Supp. 661 (2d Dep't 1936). It is rejected in National Life \& Accident Ins. Co. v. Holbrook, 100 F.2d 780 (5th Cir. 1939) ; National Life \& Accident Ins. Co. v. Clayton, 254 Ala. 413, 48 So.2d 180 (1950). Where the applicant knew of the rejection or counter-offer, recovery is denied. Insurance Co. v. Young's Adm'r, 23 Wall. 85 (U.S. 1874); Kronjaeger v. Travelers Ins. Co., 124 W. Va. 730, 22 S.E.2d 689 (1942).

79. For a concise criticism of this result, see Note, 60 HAkv. L. REv. 1164, 1165 (1947).

80. See, e.g., Raymond v. National Life Ins. Co., 40 Wyo. 1, 273 Pac. 667 (1929) (applicant suffered from a stomach ailment). But see National Life \& Accident Co. v. Clayton, 254 Ala. 413, 48 So.2d 180 (1950) (beneficiary recovered although applicant was discovered to have cancer a few days after medical examination). Misrepresentation by the applicant as to his physical condition may be a further reason for the rule of instant termination. Note, 60 HARv. L. Rev. 1164, 1165 (1947). And in at least one case the court apparently regarded the binder as ineffectual in the first place. Mohrstadt v. Mutual Life Ins. Co., 115 Fed. 81 (Sth Cir. 1902).

81. Recovery is allowed on the theory that under this type of binder the company cannot arbitrarily reject the applicant by hindsight if he was a satisfactory risk on the date of the binder. Western \& Southern Life Ins. Co. v. Lottes, 116 Ind. App. 559, 64 N.E.2d 405 (1946); Wolfskill v. American Union Life Ins. Co., 237 Mo. App. 1142, 1146, 172 S.W.2d 471, 472 (1943). 
Laddor v. Life \& Casualty $C$. of Temesse..$^{22}$ There the applicant, holling an insurable risk binder. died while the company was considering his cass. Despite the fact that a home office inspector har found him to he an insurallh. risk, his beneficiary could not recover. The court, rejecting objective staniards of insurability, argued that only an officer of the company cullul letemine whether the applicant was insurable. Otherwise, reasoned the court, the ayent would, in effect, be binding the company and this was heyoml the ser,je of hi: agency. $\$ 3 \mathrm{By}$ superimposing the approval requirement upan an in-uralle risk binder this court wipes out whatever difference there may he hetween them.

The results of post-nortem rejections involving approval linters are exen more confusing. Roughly half of all binder receipt casts fall into thi. categury, The decisions are equally divided as to whether recorery shuml le all wewl:When the applicant is not an acceptable risk, cuurts read an insuralle rish requirement into approval binders. ${ }^{85}$. Ipparently feeling it uniair to : adile companies with risks they would never approve, courts deny recrivery where the applicant was uninsurable. Eren where the applicant is insurahle, many courts deny recovery on the ground that the company has nut acepted the applicant's offer. ${ }^{86}$ However, more decisions, typified by Gantut a. John Honcock, $\$$ hold the company liable in this situation by construing an "ambiguity" against it, or by reasoning that denial of recovery would be unconscionable. ${ }^{8 s}$

82. $79 \mathrm{Ga}$. App. 164, 53 S.E.2d 235 (1949).

S3. Id. at 173-5, 53 S.E.2d at 241-2.

84. Recovery allowed: Reck v. Frudential Ins. Co. of Ameria, 116 X.J.L. 444, 184 Atl. 777 (1936); Hart v. Travelers Ins. Co., 236 App. Div. 309, 258 X.Y. Supp. 711 (2d Dep't), aff'd, 261 N.Y. 563, 185 N.E. 739 (1932); Dunean v. John Hancods Mutual Life Ins. Co., 137 Ohio St. 550, 31 N.E.2d \&S (1940). Recovery denied: Northwestem Miutual Life Ins. Co. v. Neafus, $145 \mathrm{Ky}$. 563, 140 S.WV. 1026 (1911); Arcuri v. Prudential Ins. Co. of America, 248 App. Div. 501, 290 N.Y. Supp. 567 (1st Dep't 1936) ; Check v. Pilot Life Ins. Co., 215 N.C. 36, 1 S.E.2d 115 (1939).

85. Northwestern Mutual Life Ins. Co. v. Neafus, $145 \mathrm{Ky} .563,140$ S.IV. 1026 (1911). If the applicant had been an insurable risk "we would have a very different questiun," id. at 573, $140 \mathrm{~S} . \mathrm{IW}$. at 1031. See also Indiana National Life Ins. Co. v. Miaines, $191 \mathrm{Ky}$. 309, 230 S.W. 54 (1921).

86. See, e.g., Beaty v. Southland Life Ins. Co., 28 S.W.2d 895 (Tex. Civ. App. 1930) ; Cooksey v. Mutual Life Ins. Co., 73 Ark. 117, 83 S.W. 317 (1944). Recovery is also denied because the binder's terms "require" this result. E.g., Hyder v. Aletropolitan Life Ins. Co., 183 S.C. 98, 190 S.E. 239 (1937).

87. Gaunt v. John Hancock Mutual Life Ins. Co., 160 F.2d 599, 601 (2d Cir. 1947). See also Duncan v. John Hancock Mutual Life Ins. Co., 137 Ohio St. 441, 31 N.E.2d 83 (1940) ; Hart v. Travellers Ins. Co., 236 App. Div. 309, 258 N.Y. Supp. 711 (2d Dep't), aff'd, 261 N.Y. 563, 185 N.E. 739 (1932).

SS. Reck v. Prudential Ins. Co. of America, 116 N.J.L. 444, 184 Atl. 777 (1936); Reed v. Prudential Ins. Co., 229 Mo. App. 90, 73 S.W.2d 1027 (1934); Mayfield v. Montana Life Ins. Co., 62 Mont. 535, 205 Pac. 869 (1922). 


\section{Summary'}

Generally an insurable risk binder protects the applicant so long as he has not received notice of rejection or counter-offer. ${ }^{80}$ While recovery is not certain on these binders, it is, with the exception of the Maddo.t case, denicd only where the applicant was not an insurable risk. ${ }^{80}$ Insurable risk hinders form a small proportion of the cases, perhaps indicating that because of their greater clarity, the questions of coverage under them are more easily settled without resort to litigation. ${ }^{91}$

The approval binder situation is less clear. It seems that an approval binder will not help the beneficiary if the applicant was uninsuralle. ${ }^{92} \Lambda$ nd when there is an uncommunicated rejection the company is probably not liable, ${ }^{93}$ although this may simply be another form of the requirement that the applicant be an insurable risk. Where the company refuses payment because of the applicant's interim death, his beneficiary has no more than an even chance to recover. However, if the company accepts after cleath the majority rule holds it liable.

Thus, the combination of the verbal and factual analyses does not dispel the confusion. While insurable applicants recover under insurable risk binders, they may or may not recover under the approval type. The fact situations are irrelevant where an insurable risk binder is issued, and they are not controlling in the approval binder situation. Thus, absent an insurable risk binder, it is virtually impossible to tell whether a binding receipt actually binds. ${ }^{0 .}$

\section{Recovery Denied}

\section{Rationales of Results}

Denial of recovery on the ground that the applicant was not an insurable risk, ${ }^{95}$ is not subject to criticism. Here the company would seem justified in refusing payment since in no circumstances does it accept such applications. Nor can it be argued that the deceased relied on the binder to his detriment, because he would not in any case have been able to obtain insurance elsewhere.

But the offer and acceptance approach requires a logical leap of some proportions. It equates the binder with the application as a mere offer, having

89. See pages 529-30 supra.

90. See page 529 and cases cited note 74 supra.

91. Approximately one-fifth of the appellate cases involve insurable risk binders, although they are probably issued as frequently as approval binders. VANCE, INSUMANCE 239 (1951). Cf. Patterson, Cases on Insurance 629 (1949).

92. See pages 530-1 supra.

93. See page 530 sicpra.

94. Moreover, the tendency of some courts to change their minds encourages further litigation even in a jurisdiction which has ruled decisively. For examples of judicial vacillation, see notes $46-9$ supra.

95. Reynolds v. Northwestern Mutual Life Ins. Co., 189 Iowa 76, 176 N.W. 207 (1920) ; Northwestern Mutual Life Ins. Co. v. Neafus, 145 Ky. 563, 140 S.W. 1026 (1911). 
no effect until accepted by the company. ${ }^{90}$.nd acceptance after the applicant ${ }^{\circ}$ s death is held ineffective since the offer was "revolied" at the moment of death. ${ }^{97}$ The binder is issued for a separate consideration, ${ }^{98}$ not as a necessary part of the application. It is difficult to see how the applicant's payment of money in return for a recital of coverage can be an offer in any event. He obviously is not offering to be insured, since his application does this regardless of whether he pays a premium in advance. If offer and acceptance must be brought into the discussion, the shoe would seem to fit hetter on the other foot. The company states that if the applicant pays a premium with his aplitication it will advance the date of coverage. This offer the applicant accent by parting with his money.

Another theory reads the binder as a statement that liability will commente when the company accepts the application with the policy dating frem is man;e of the binder." Courts hold consideration for the applicant's parmen is inum! in certain "esoteric" collateral advantages comprehensible only" th unilerwriters. ${ }^{100}$ This line of reasoning is, however, out of step with reality. The terms may have some meaning to a judge schooled in the fine print of insurance clauses. But it is rather doubtful if the arerage applicant will realize that the binder's apparent promise of immediate corerage does not mean what it says. If an applicant should question the effect of the binder, the agent may tell him that he is protected "from now on." "n's Furthermore, the use of

96. Mohrstadt v. Mutual Life Ins. Co., 115 Fed. Si (Sth Cir. 1902); Beaty v. South. land Life Ins. Co., 28 S.WW.2d 895 (Tex. Civ. App 1930); see Kromjaeger v. Travelers Ins. Co., 124 W. Va. 730, 22 S.E.2d 689 (1942).

97. Braman v. Mutual Life Ins. Co., 73 F.2d 301 (Sth Cir. 1934); Paine v. Pasific Mutual Life Ins. Co., 51. Fed. 689 (Sth Cir. 1892).

98. The payment of the first premium in advance is the consideration.

99. Cheek v. Pilot Life Ins. Co., 215 N.C. 35, 1 S.E.2d 115 (1939); Corning v. Yru= dential Ins. Co. of America, 248 App. Div. 187, 288 N.Y. Supp. 651 (2d Dep't 1936): Smiley v. Prudential Ins. Co. of America, 321 Mich. 60, 32 N.W.2d 48 (1948).

100. Gaunt v. John Hancock IIutual Life Ins. Co., 160 F.2d 599, 602 (2d Cir. 1947). In this case the company suggested six "advantages" to the applicant that could result from dating the policy from the binder without granting coverage These were: (1) earlier date of incontestability; (2) earlier maturity and acceleration of dividends and cash surrender; (3) coverage between approval and delivery of the policy; (4) coverage for the applicant even if he became uninsurable between completion of the medieal examination and approval of the policy (sic); (5) premiums at the lower rate if he passed a birthday between application and approval; $(6)$ if the poliey were vritten to cover disability as well as death, the applicant would be protested against disability from the binder's date $I d$. at 601 . The court dismissed these alleged advantages as insubstantial. Id. at 602-03.

101. Statements of this nature appear repeatedly in the litigated eases. See, c.g., Maddox v. Life \& Casualty Co. of Tennessee, 79 Ga. App. 164, 53 S.E.2d 235 (1949); Himes v. Metropolitan Life Ins. Co., 207 S.C. 40, 36 S.E.2d 137 (1945). And sse note 12 supra.

Since these statements are beyond the scope of the agency and are not authorized by the company, the beneficiary of a deceived applicant cannot bind the company by them. Cheek v. Pilot Life Ins. Co., 215 N.C. 36, 1 S.E.2d 115 (1939) ; Lraman v. Ifutual Life 
the words "binding receipt" appears calculated to induce in the applicant an expectation of immediate coverage. ${ }^{102}$ The collateral advantages may constitute a minimal consideration. ${ }^{103}$ But the applicant is not getting the one thing he is paying for-insurance. In view of the applicant's natural belief that he is covered, refusal of recovery turns the binding receipt into an instrument of deception. While the company clemands premiums from the date of application, it grants coverage only from the date of approval.

\section{Recovery Allowed}

The theory allowing recovery by construing "ambiguities"101 against insurance companies is far from satisfactory. Its greatest defect lies in the uncertainty it leaves as to binders with slightly clifferent wording. This uncertainty invites litigation. Company draftsmen search for an alchemy of words which no court can find ambiguous. The small amount involved in many of the litigated cases indicates that even a victorious beneficiary may see the proceeds of his policy virtually wiped out by costs and fees. ${ }^{105}$

A second theory of recovery finds the insured's payment of the prenium unsupported by consideration unless he obtains immediate coverage. ${ }^{101}$ But the applicant does receive something, albeit of little value, for advance payment of the first premium. And courts, under traditional contract doctrine, will not inquire into the adequacy of consideration. But the argtment for recovery emphasizes that only immediate insurance is important to the applicant. Stating the result in terms of the inadequacy of collateral benefits as consideration points up the basic inequity of denying recovery.

A more direct attack on this problem is made when courts allow recovery because any other result would be "unconscionable." 107 This approach goes to the heart of the problem by restricting the company's freedom of contract

Ins. Co., 73 F.2d 391. (8th Cir. 1934) ; Beaty v. Southland Life Ins. Co., 28 S.W.2d 895 (Tex. Civ. App. 1930). Contra: Mayfield v. Montana Life Ins. Co., 62 Mont. 535, 205 Pac. 699 (1922).

102. See Cheek v. Pilot Life Ins. Co., supra note 101 at 39, 1 S.E.2d at 116.

103. Schultz, The Spicial Nature of the Insurance Contract, 15 Law \& Contestr. PRoB. 376, 383 n.28 (1950).

104. Courts are sometimes willing to strain to find ambiguities. Schultz, supra note 103 , at 379.

105. In one action the policy's total worth was $\$ 500$, attorney's fee was $\$ 225$, or $45 \%$ of the face value. Colorado Life Co. v. Teague, 117 S.W.2d 849, 851 (Tex. Civ. App. 1938). Some state insurance statutes provide that the plaintiff may recover his costs and fees plus a statutory penalty against the company if he wins his case. But such recovery is usually limited to cases where the company's refusal to pay is frivolous. See, c.g., GA. CODE ANN. tit. 56, §706 (1935).

106. Stonsz v. Equitable Life Assur. Soc., 324 Pa. 97, 187 Atl. 403 (1936); Hart v. Travellers Ins. Co., 236 App. Div. 309, 248 N.Y. Supp. 711 (2d Dep't 1932).

107. Colorado Life Co. v. Teague, 117 S.W.2d 849 (Tex. Civ. App. 1938) ; Western \& Southern Life Ins. Co. v. Vale, 213 Ind. 601, 12 N.E.2d 350 (1938). "[I]t means that by a device calculated to deceive, the applicant is defrauded out of so much of the premium as would provide insurance. ..."Id. at 610,12 N.E.2d at 354 . 
in the name of fairness. ${ }^{10 s}$ It recognizes that insurance contracts are sui generis. ${ }^{109}$ One assumption of freedom of contract is relative equality of bargaining power. And another is workable competition among sellers, enabling buyers to shop around for the most favorable terms. ${ }^{110}$ In the binder situation. however, the applicant has no equality or hargaining puwer with the insurance company. Neither can he adequately compare the contents of various insurance policies. ${ }^{111}$ Since the hasic assumptiuns unlerlying the traditional unwillingness of courts to police contracts are alosent, an approach which prorides protection of the applicant is essential.

\section{Conclu'sion}

In the more recent cases, there has lieen a tenkency to allow recovery, if the applicant was an insurable risk, regardless of the type of binder in questiun. The stated grounds of recovery have varied, hut the more flexible use of doctrine, and the language sometimes employed, indicates increasing judicial awareness of the necessity of protecting the applicant. ${ }^{112}$ This trend toward treating all binders as if they simply required that the applicant he an insurable risk is gradual. And some courts, perhaps believing freedom uf contract inviolable, reject it. ${ }^{113}$ Thus, the present confusion is not likely to dissipate rapidly. Noreover, even in jurisdictions where the legal effert of binding receipts appears settled, the social costs of litigation continue.

As things stand, only statutory control of linding receipts would satisiactorily protect the applicant and dispel prevailing confusiun. Legislatures have in the past been willing to enact regulations ${ }^{114}$ for the protection of the insured. ${ }^{115}$

108. Divergent views as to the relative impurtance of ircedom of contract as compared with the necessity of protecting the applicant may be the real basis of disagrement among the courts. This theory has been put forward on several occasions. Kessler, Corttracts of Adhesion-Some Thoughts about Frecdan of Contrast, $43 \mathrm{CoL}$ L. Rev. 629 (1943) ; Schultz, sispra note 103, at 377. Support for the view that the cleavge runs along philosophical rather than legal lines may be drawn from ureasional judicial statements. Ibid.

109. German Alliance Ins. Co. v. Kansas, 233 U.S. 389, $412-13$ (1914). Life insurance is vital to many individuals as a form of security for dependents, as a primary collection of savings and as acceptable collateral for loans. Schultz, supra note 103.

110. Kessler, supra note 108 , at 630 .

111. Patterson, The Instranice Cumamssioner in the Umited Siates 246 (1927).

112. See, e.g., Gaunt v. John Hancock MIutual Life Ins. Co., 160 F.2d 599, 602-03 (2d Cir. 1947); Western \& Southern Life Ins. Co. v. Vale, 213 Ind. 601, 610, 12 N.E.2d 350,354 (1938).

113. See, e.g., Hughes v. John Hancock Mutual Life Ins. Co., 163 Misc. 31,297 X.X. Supp. 116 (Mun. Ct. 1937) : "[I]nterpretation of binder in favor of plaintifi would violate the elementary principles of freedom of contractual rights." Id. at 35, 297 N.Y. Supp. at 122 .

114. See statutes cited note 14 supra.

115. Typical of regulations for the benefit of the applicant and his teneficiary are provisions regulating the use of representations or warranties of the applicant as grounds 
There are at least two statutory methods of protecting the applicant who pays his first premium in advance. A compulsory binding receipt form coutld be set forth. ${ }^{116}$ The required terns would guarantee coverige to the insturable applicant from the date of payment until he receives notice of acceptance or rejection. ${ }^{117}$ An alternative statute would require coverage of the insurable applicant who pays his premium in advance, regardless of whether a bincle $r$ is actually issued. In either case, an objective test of insurability should be applied. Under this test the applicant is covered if a reasonably careful insurer would have accepted him. A subjective test would allow the company to avoid the effect of the statute by contending that it did not consirler the applicant insurable. ${ }^{118}$ Since the facts bearing on such a contention are peculiarly within the company's knowledge and control, it would be unfair to refuire the beneficiary to disprove them.

While either statutory solution would be an improvement, the second is the more satisfactory. A company should in fairness grant coverage if it protects itself by demanding payment in advance. But the company can avoid liability under the "compulsory terms" statute by simply not isstuing any" binder. ${ }^{119}$ Moreover, if protection rests on issuance of a binder, the beneficiary may lose because the agent neglected to offer a bincler to his customer.

Thus, a model binding receipt statute should provide:

"Section $X$. a) Whenever an Insurance Company accepts payment of the first premium on a policy of life insurance prior to the delivery of said policy to the applicant, insurance shall be in effect from the date of such payment to the same extent as if the policy applied for had been delivered. Provided: that on the date of payment the applicant was in fact an insurable risk under standards generally applied by reputable insurance companies. Provided further: that an insurance company may terminate liat-

for avoiding liability. See N.Y. Insurance LAW $\$ \$ 149,150$ (1939). For a discussion of the reasons behind the enactment of these sections see Note, 40 CoL. L. REv. 880 (1940).

116. Eight sections of the $\mathrm{New}$ York Insurance Code provide standard provisions for life insurance policies. N.Y. Issurance Code $\$ \$ 155,158-64$ (1939).

117. At present, there is a tendency among insurance companies to issue binders of this type rather than approval binders. Moreover, some companies treat approval binders as if they were insurable risk binders. Wilkinson, supra note 2 , at 28 .

118. For a discussion of the advantages of the objective test sce Kessler \& Ehrenzweig, IIisrepresentation and False Warranty in the Illinois Insurance Code, 9 U. or Cur. L. Rev. 209, 213-14 (1942). For a defense of the subjective test see Note, 40 Col. L. REv. 880,887 (1940).

119. An additional advantage of the automatic coverage solution is that it settles the oft-litigated question of the company's liability, absent a binder, for unreasonable delay in acting on applications. Where the company fails to act promptly and the applicant dies before delivery of the policy, some courts have strained tort and contract doctrines to allow recovery. Others have refused to do so; there is little correlation between denial or allowance of recovery in tort and the state's rule on binding reccipts. The cases arc collected in Prosser, Delay in Acting on an Application for Insurance, 3 U. of Cur. L. REv. 39, 41-3 (1935). The proposed statute protects insurable applicants who prepay their premium against the company's tardiness. 
bility under this section by delivery to the applicant in his lifetime of notice that his application has been rejected as to the policy applied for, and simultaneous tender of the amount paid.

b) This section shall apply regardless of whether or not the applicant receives a receipt that purports to bind the company, except that a company may provide temporary coverage for an applicant regardless of whether the applicant was an insurable risk at the time of payment.

c) Nothing in this section shall be construed as limiting any defense an insurance company might have to liability, had the policy been delivered." 120

120. Sub-section $a$ 's first proviso prevents the company from being saddled with poor risks. And it adopts an objective standard for determining whether the risk was satisfactory.

Sub-section $b$ allows a company, if it so desires, to bind itself absolutely upon receipt of payment in advance, fending action on the applicatiun.

Sub-section $c$ preserves the company's right to interpose defenses it would have against a delivered policy, such as material misrepresentation and lack of insurable interest. 